\title{
The Hungarian Hubris Syndrome
}

\author{
Lilla Magyari, ${ }^{1,2 *}$ Csaba Pléh $^{3}$, and Bálint Forgács ${ }^{4}$ \\ ${ }^{1}$ Department of Social Studies, University of Stavanger \\ ${ }^{2}$ Norwegian Reading Centre for Reading Education and Research, University of \\ Stavanger \\ ${ }^{3}$ Department of Cognitive Science, Central European University \\ ${ }^{4}$ Department of Cognitive Psychology, Eötvös Loránd University (ELTE)
}

\begin{abstract}
Author Note
Draft version $1.3,12 / 8 / 21$. This paper has not been peer reviewed.

This study was not preregistered.

All raw data is publicly available on the official website of the Hungarian Parliament (kormany.hu, 2021). Data selected for the analyses and data analysis code is available upon
\end{abstract} request.

We have no conflict of interest to disclose.

We are grateful to Gábor Prószéky for his help with the grammatical parser and to Nguyen-Dang Nóra Lien for her enormous help with the organization of the speech corpus.

The authors received no financial support for the research, authorship, and/or publication of this article. 


\begin{abstract}
Powerful figures, such as politicians, who show a behavioural pattern of exuberant selfconfidence, recklessness, and contempt for others may be the subject of the acquired personality disorder, the hubris syndrome, which has been demonstrated to leave its mark on speech patterns. Our study explores characteristic language patterns of Hungarian prime ministers (PMs) with a special emphasis on one of the key indicators of hubris, the shift from the first person "I" to "we" in spontaneous speech. We analyzed the ratio of the first-person singular ("I") and plural ("we") pronouns and verbal inflections in the spontaneous parliamentary speeches of four Hungarian PMs between 1998-2018. We found that Viktor Orbán during his second premiership (2010-2014) used first person plural relative to singular inflections more often than the other three PMs during their terms. Orbán and another Hungarian PM, Ferenc Gyurcsány, who were re-elected at some point showed an increased ratio of first-person plural vs. singular inflections and personal pronouns by their second term, likely reflecting the process of getting drunk with power. The results show that linguistic biomarkers of hubris identified in English text in earlier studies can be also found in a very different language, Hungarian and confirm the hypothesis that extended periods of premiership increase hubristic behaviour in political leaders. The results especially illuminate the role of re-elections in PMs' hubristic behaviour.
\end{abstract}

Keywords: hubris, Hungarian language, first-person plural, personal pronouns, verb conjugations 


\section{The Hungarian Hubris Syndrome}

Over a decade ago David Owen and Jonathan Davidson (2009) proposed a new kind of personality disorder, which may be acquired by successful political leaders exactly because of their success: the hubris syndrome (HS). Since then the idea has emerged that particular speech features of political and business leaders may not only report how spoiled they are by power, but could be used as linguistic biomarkers with diagnostic value (Akstinaite, 2018; Craig \& Amernic, 2018; Garrard, 2018; Garrard et al., 2014; Owen, 2008; Owen \& Davidson, 2009). The present paper sets out to identify individuals affected by HS among Hungarian prime ministers (PMs) based on the linguistic markers expressed in their spontaneous speech.

The overconfidence and sense of invulnerability observed in leadership-behaviour, described originally in behavioural finance as hubris hypothesis (Roll, 1986), was suggested to lead to disadvantageous decisions and misjudgements or even unethical behaviour (Asad \& Sadler-Smith, 2020; Cormier et al., 2016; McManus, 2018; Sadler-Smith et al., 2017) (even though some positive consequences have been pointed out recently; Zeitoun et al., 2019). Hubristic behaviour of political leaders has got into the spotlight with the recent rise of populism (Körösényi et al., 2020; Owen, 2018). Based on the behavioural pattern and medical history of politicians, being spoiled by power has been conceptualized as an acquired personality disorder due to a sustained experience of excessive power (Owen, 2008; Owen \& Davidson, 2009). Owen and Davidson (2009) described HS in medical terms as a disorder with fourteen diagnostic criteria including verbal behaviour, speaking style and word choices. However, HS might be more akin to a personality trait rather than a personality disorder, since it usually appears later in life as a consequence of and during holding a powerful position (Ghaemi et al., 2016). 
In their landmark study, Garrard et al. (2014) provided a detailed linguistic analysis of the parliamentary speeches of UK PMs and identified speech patterns linked to HS. Both Margaret Thatcher and Tony Blair showed a higher ratio of using the first-person plural pronoun, "we" relative to its singular pair, "I", during periods of their governance, when they expressed multiple additional behavioral markers of HS. Ensuing studies used text analysis tools to study the hubristic language use of CEOs (Akstinaite et al., 2020; Craig \& Amernic, 2014, 2018). Akstinaite et al. (2020) confirmed that personal pronouns, and specifically the use of "we", is a strong and diagnostic marker of hubristic language; whereas narcissism, a closely related personality disorder, has been found to correlate with the second person pronoun "you" (Holtzman et al., 2019), and not with "we". In sum, the high proportion of "we" in natural speech seems to be a powerful linguistic biomarker of hubristic personality traits with differential diagnostic value. For this reason, we decided to focus our inquiry on this particular linguistic feature.

Among prime ministers of Hungary, Orbán has been in power for the longest period since the fall of the iron curtain, between 1998 and 2002 and since 2010 to this day, which makes him particularly vulnerable to HS. It has also been suggested that subsequent reelections might increase the chance for hubris (Ghaemi et al., 2016). Orbán’s political behaviour and leadership style from his second term onwards (since 2010), relative to his first premiership (between 1998-2002) is consistent with this idea: he is renowned for limiting challenges to his power by tampering with electoral laws and the constitution, constraining free speech and independent media, and eroding civil and human rights in Hungary since his re-election (Board, 2018; Körösényi et al., 2020). In the past decade he has been regarded as an authoritarian populist leader at the far right of the political spectrum (Körösényi et al., 2020), on par with Erdogan in Turkey or Putin in Russia. 
The particularities of Hungarian language allow for specific predictions on hubristic linguistic markers. In Hungarian, subject pronouns are regularly dropped in sentences, with number and person expressed by verb conjugation. Personal pronouns can also be included in sentences, but they are utilized usually for emphasis, such that, most personal pronouns in subject roles are contrastively focused (É. Kiss, 2012). Thus, not only the usage patterns of first-person pronouns but also verbal inflections are highly informative regarding speech patterns in Hungarian.

For our investigation we sought for official but spontaneous political speeches. To this end, we selected speeches from the official records of the Hungarian parliament that were not possible to write in advance. Our hypotheses are the following: Orbán, due to hubristic personality trait uses the personal pronoun "we" in a higher proportion relative to "I" (WE:I ratio) in his speech than other former Hungarian PMs from his second premiership onwards. We expect the WE:I ratio to remain consistent during his years in power since 2010, as hubris, once triggered, should be present as long as its triggering conditions are met. Further on, as verbal suffixes carry number and person marking in Hungarian, we also predict that the WE:I ratio effects will be present in first person verb conjugations as well.

\section{Methods}

\section{Subjects}

Speeches of all Hungarian PMs were studied who governed for various durations between 1998-2018. Parliamentary elections are held every four years in Hungary, but the ruling party may switch PMs, which led to seven governments headed by four PMs during this period. Two out of the four PMs, Orbán and Gyurcsány, held office more than once (Figure 1, and see also Subjects in Supplemental Materials). 


\section{Figure 1}

Timeline of Parliamentary Cycles and Prime Ministers in Hungary From 1998 to 2018

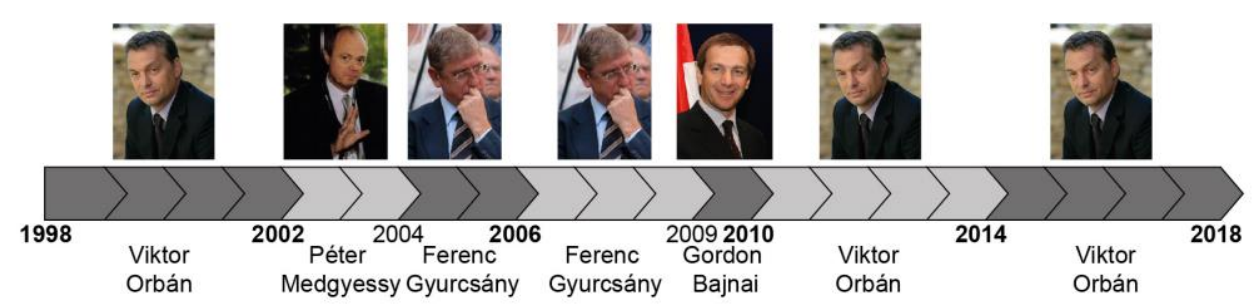

Note. The bottom line shows the name of the PMs and years of change in PM and/or the years of parliamentary elections (the later are in bold). All images are downloaded from Wikimedia Commons (commons.wikimedia.org; Orban Viktor Portrait.jpg, kormany.hu, 2010, CC BY-SA 2.5; Medgyessy Péter 2002.jpg, Tamás Griechisch, 2002, CC BY-SA 4.0; Gyurcsány and Medgyessy (Aug 2014).jpg, Tibor Végh, 2014, CC BY 3.0; Bajnai Jerusalem.jpg, Itzike, derivative work by Qorilla, 2009, CC BY-SA 3.0).

\section{Speech Samples}

Similarly to Garrard et al. (2014), transcripts of public speeches on plenary sessions of the Hungarian Parliament were obtained. Instead of analysing spoken utterances of interviews (e.g., see Akstinaite et al., 2020), we used parliamentary speeches because this allowed us to compare spoken utterances arising from a similar context and situation among different prime ministers. The parliamentary records from 1998 include a classification system which helped us to select those speeches which are the most spontaneous and to avoid prepared speeches which might be written by professional speech writers. We chose the following categories of speeches of all politicians who were prime ministers between 1998 and 2018 in Hungary: 1) two-minute interventions: a remark during general debate with permission from the parliament 
chair. 2) reply: reply by the speaker during general debate; 3) re-replies: one-minute re-replies to replies by speakers to so called immediate questions. Altogether 454 replies and interventions were selected from the four PMs through seven parliamentary cycles from July $6^{\text {th }}, 1998$ to May $7^{\text {th }}, 2018$. All selected speech samples were parsed for grammatical structure (Proszeky \& Kis, 1999). Using the grammatical parser, we retrieved the first person singular ("I") and plural ("we") personal pronouns (PP) and verbs with first person singular and plural verbal inflections (verb conjugations, VC) for all samples. The form of the nominative case of the first-person plural pronoun, "mi" in Hungarian ("we" in English) is the same as a less frequent variation of the relative pronoun "what". Therefore, a research assistant checked all speech samples manually and corrected in the data table if the word "mi" was wrongly categorized by the analyser, and the lead author of the study checked again if the manual corrections were well done. Number of PPs and VCs and speech samples used for data analysis are shown in Table 1.

\section{Table 1}

Frequencies of First-Person Personal Pronouns and Verb Conjugations in the Parliamentary Speeches of the Four Hungarian PMs

\begin{tabular}{lcccccc}
\hline & \multicolumn{3}{c}{$\begin{array}{c}\text { First-person personal } \\
\text { pronouns }\end{array}$} & \multicolumn{3}{c}{$\begin{array}{c}\text { First-person verb } \\
\text { conjugations }\end{array}$} \\
\cline { 2 - 7 } Prime ministers & $\mathrm{n}$ & $\%$ & $\mathrm{n}$ (s.s.) & $\mathrm{n}$ & $\%$ & $\mathrm{n}$ (s.s.) \\
\hline P. Medgyessy (2002-2004) & 58 & 31 & 30 & 436 & 32 & 59 \\
F. Gyurcsány & & & & & & \\
First (2004-2006) & 26 & 23 & 15 & 210 & 30 & 32 \\
Second (2006-2009) & 84 & 54 & 12 & 317 & 45 & 17 \\
G. Bajnai (2009-2010) & 42 & 38 & 17 & 228 & 36 & 27 \\
V. Orbán & & & & & & \\
First (1998-2002) & 57 & 42 & 26 & 379 & 32 & 53 \\
Second (2010-2014) & 203 & 57 & 73 & 875 & 46 & 101 \\
Third (2014-2018) & 229 & 54 & 92 & 954 & 40 & 137 \\
\hline
\end{tabular}

Note. $\mathrm{n}$ (s.s.) $=$ number of speech samples. $\%=$ percentage of plurals 


\section{Statistical Analyses}

The amount of PP and VC within speech samples and the number of speech samples per PM and parliamentary cycles varied considerably (Table 1), therefore, we used generalized linear mixed-effect model (GLMM) analysis to control for the varying occurrences of these. Binomial GLMMs were fitted on two categorical response variables, 1) on the singular and plural first-person personal pronouns (PP), i.e. "I" and "we" and their variations (singular = 1, plural $=2)$ and 2$)$ on the singular and plural first person verb conjugations $(\mathrm{VC})($ singular $=1$, plural =2), using the glmer() function of the lme4 package in R (Bates et al., 2015). We included speech sample as a random factor in our models. Fixed effects were the PMs and/or their terms of premiership. Models with more than one fixed effect included an interaction term only if it significantly improved them. The significance of interaction between fixed effects and the significance of the fixed effects were evaluated by model comparison with likelihood ratio test. When the GLMM contained one significant fixed effect with more than two levels, the model was run repeatedly, each time with a different reference-category for the fixed effect. The coefficients of the categories of fixed effects revealed whether they are different from the coefficient of the intercept (i.e., from the reference-category). This way, we could also test the differences between each of the levels of the fixed effect.

Model diagnostics were applied using the DHARMa package (Hartig, 2021). It used a simulation-based approach to create readily interpretable scaled (quantile) residuals for fitted (generalized) linear mixed models. If the model diagnostics returned any errors with the model, we excluded outlier speech samples that contributed extremely high amount of data (more than 50 items) in order to reduce variation between samples. Then, the GLMM analysis was run again on the newly reduced dataset. 


\section{Transparency and Openness}

All raw data is publicly available on the official website of the Hungarian Parliament (kormany.hu, 2021). We follow JARS (Appelbaum et al., 2018) and we report our method for selecting data and for excluding outliers if it was necessary. Data selected for the analyses and data analysis code is available upon request. Data were analyzed using R version 4.1.2 (R Core Team, 2021). This study's design and its analysis were not preregistered.

\section{Results}

\section{Personal Pronouns}

First, we compared the ratio of singular and plural first-person PP (WE:I ratio) among the four PMs (Figure 2A).

\section{Figure 2}

Percentage of Plurals (WE) Within all First-person Personal Pronouns ("I" and "we”) (A) and Verb Conjugations $(B)$

A First person personal pronouns

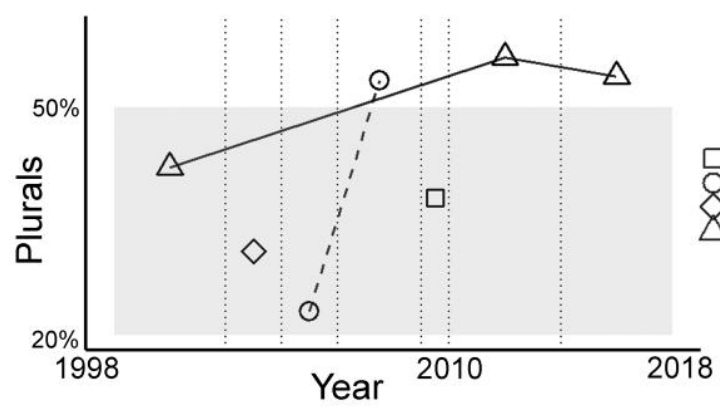

B First person verb conjugations

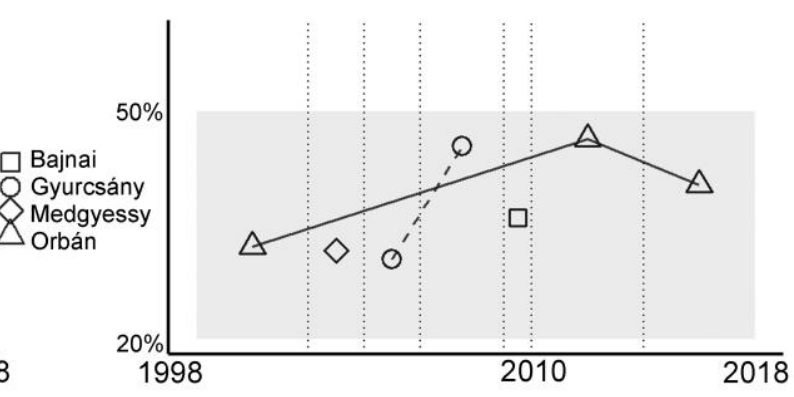

Note. Data shown for each parliamentary cycle (vertical dotted lines on y-axis) and for each PM (symbols). 
The number of all speech samples and the number of PPs ("we" \& "I") were very different across PMs. Orbán had largest number of items and speech samples. However, we hypothesized that Orbán acquired hubristic traits from his second premiership (between 2010-2014). Therefore, we used speech samples of one single term for each PM and we selected the second term of premiership for Orbán and for Gyurcsány (Table 1).

The binomial GLMM showed that the WE:I ratio in PP significantly varied by PM, $X^{2}(3)=10.33, p=.016$; Intercept (reference category: Orbán), $\beta=0.288, \mathrm{SE}=0.196, z=$ 1.467, $p=.142$; Figure 3A. There were less plurals ("we") in PP for Medgyessy compared to Orbán $(\beta=-1.219, \mathrm{SE}=0.42, z=-2.90, p=.004)$. The difference was marginal between Orbán and Bajnai $(\beta=-0.858, \mathrm{SE}=0.469, z=-1.83, p=.067)$. There were no other differences between PMs.

\section{Figure 3}

Mean of the Categorical Variable Coding the First-Person Plural ("we”) and Singular("I") Personal Pronouns (Panel A) and Verb Conjugations (Panel B) for Each Hungarian PMs
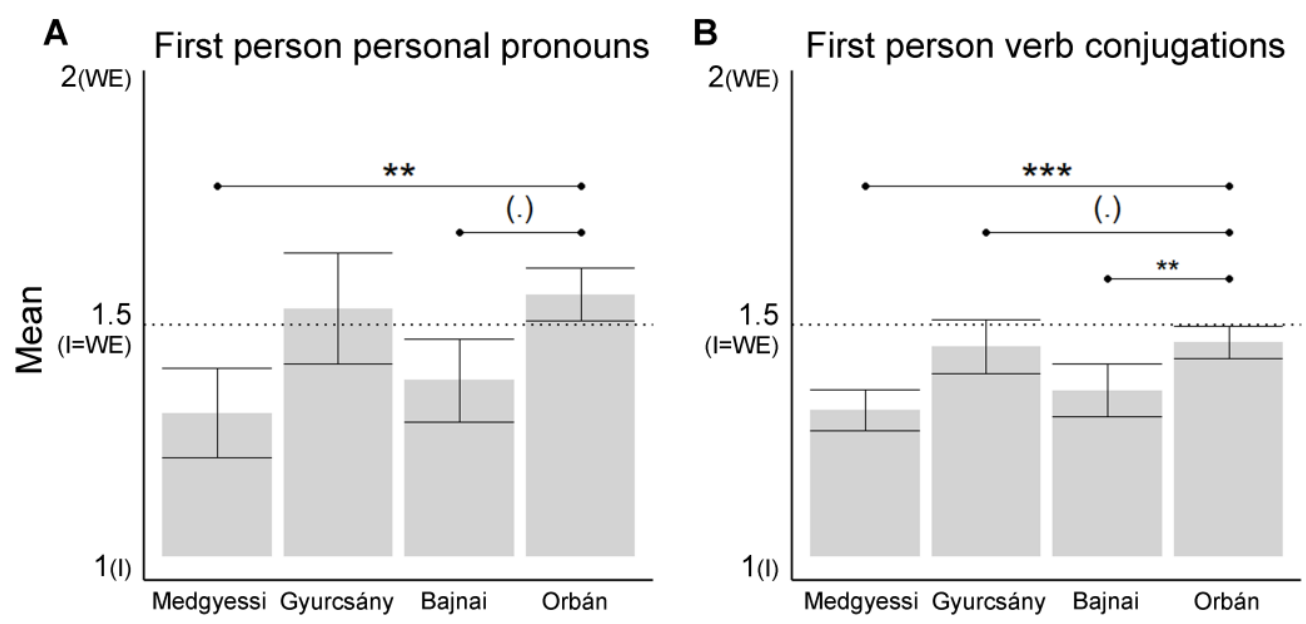

Note. X-axis shows Hungarian PMs. On the y-axis 1 indicates the exclusive use of "I", while 2 indicates the exclusive use of "we". For Gyurcsány and Orbán, the second term of their 
premiership is plotted. Error bars show confidence intervals, horizontal lines show significant differences and trends between PMs.

(.): $p<.1 . *: p<.05 . * *: p<.01 . * * *: p<.001$.

We also tested whether there was a difference between the first and second premiership for Orbán and Gyurcsány (Table 1). There was no difference between the two PMs but there were more plurals in their second term compared to their first premiership, $X^{2}(3)=10.33, p=.016, \beta=1.09, \mathrm{SE}=0.369, z=2.953, p=.003$. However, there was no difference in the WE:I ratio for PP between Orbán's second and third term, $X^{2}(1)=.249, p=$ $.6181, \beta=-0.138, \mathrm{SE}=.276, z=-0.499, p=.618$, Table 1. Model diagnostics of these analyses are shown in Figure S1 of the supplemental materials.

\section{Verb Conjugations}

The WE:I ratio for verb conjugations were also compared across PMs (Figure 2B). For Orbán and for Gyurcsány, data from their second premiership was entered into this analysis (Table 1). The binomial GLMM showed that WE:I ratio for VC, i.e., the first-person verb conjugation being singular or plural, was significantly influenced by $\mathrm{PM}, X^{2}(3)=19.01$, $p=.0006$; Intercept (reference category: Orbán), $\beta=-0.259, \mathrm{SE}=0.117, z=-2.204, p=$ .0275; Figure 3B. There was a higher ratio of WE:I for VC for Orbán compared to Bajnai ( $\beta$ $=0.54, \mathrm{SE}=0.255, z=2.113, p=.004)$ and compared to Medgyessy $(\beta=0.815, \mathrm{SE}=0.211$, $z=3.863, p=.0001)$. The difference was marginally significant between Orbán and Gyurcsány $(\beta=0.571, \mathrm{SE}=0.301, z=1.899, p=.058$; Figure 3B $)$. However, in an outlier filtered analysis, when some speech samples were excluded from the data due to poor model 
diagnostics, the statistically improved model showed significantly more plurals for Orbán relative to Gyurcsány (see Table S1-S2 and Figure S2 in supplemental materials).

There was also a difference in the WE:I ratio for VC between Orbán's and Gyurcsány's terms (first vs second), $X^{2}(1)=16.84, p<.0001$, and also between persons, $X^{2}(1)=7.17, p=.007$; Table 1 . The number of plural forms increased in the second term compared to their first term $(\beta=0.668, \mathrm{SE}=0.162, z=4.12, p<.0001)$, while Gyurcsány had fewer plural inflections compared to Orbán, $\beta=-0.507, \mathrm{SE}=0.193, z=-2.63, p<.001$. When outlier speech samples were rejected to improve model diagnostics (Figure S3), the analysis of the reduced dataset showed similar results (see Table S1, S3 and Figure S3 in supplemental materials). In his third term, Orbán's data showed a marginally lower ratio of plurals compared to his second term, $X^{2}(1)=3.77, p=.0521 ; \beta=-0.27, \mathrm{SE}=0.139, z=-$ 1.947, $p=.052$. An improved model showed similar results (see Table S1, S4 and Figure S4 in supplemental materials).

A tentative analysis of speeches of Gyurcsány and Orbán as a Member of Parliament and not as PM can be found in Supplementary Results and Supplementary Discussion of the supplemental materials.

\section{Discussion}

We investigated the speech patterns of Hungarian PMs in order to establish whether the current PM, Viktor Orbán's speech exhibits the key linguistic biomarker of hubristic personality trait, that is, the excessive use of the personal pronoun "we" instead of its firstperson counterpart "I". Our study also extends earlier research of the linguistic biomarkers (e.g., Akstinaite et al., 2020; Garrard, 2018), because the Hungarian language also allowed us to examine the WE:I ratio in terms of verb conjugations besides personal pronouns. We found that Orbán had a higher WE:I ratio both for personal pronouns and for verb 
conjugations in his second compared to his first premiership. Moreover, in his second term, Orbán's WE:I ratio for verb conjugations was higher than any other Hungarian PMs'. Another PM, Gyurcsány, who also governed for more than one parliamentary cycle, also had higher WE:I for personal pronouns and for verb conjugations in his second compared to his first term.

Earlier works found personal pronouns to be a reliable marker of personality traits and social hierarchy (Akstinaite et al., 2020; Cassell et al., 2006; Garrard, 2018; Kacewicz et al., 2014; Sakai \& Carpenter, 2011). However, most of these studies used computerized text analysis of English texts or English translation of texts written in other language (e.g., Kacewicz et al., 2014). Here, our results showed that the relative frequency of first-person personal pronouns can be still a relevant linguistic marker of hubris even in a non-IndoEuropean language, like Hungarian, in which the frequency and linguistic behaviour of pronouns are governed by to different rules compared to English. Moreover, first-person verb conjugations in Hungarian might also fulfil similar diagnostic role as personal pronouns in identifying hubristic behaviour. In our study, we found that the ratio of the plural first person pronouns and verb inflections showed almost similar results. Therefore, future research could further study whether there are the differences in the function of the two types of linguistic forms as markers of hubris.

The increase between the first and second terms for both Orbán and Gyurcsány is in line with description of the hubristic personality that states that hubris tends to develop over time following the acquisition of power. For example, Garrard et al. (2014) showed that Margaret Thatcher's usage of "we" compared to "I" peaked in the year of her re-election. But other speech corpus data confirming the effect of re-election is scarce. Orbán's WE:I ratio did not increase from his second to his third term, which suggests that the effect of hubris on these linguistic markers remained at its peak. The first re-election might be of particular 
importance. Crucially, we also found that Gyurcsány's speeches also exhibited a higher WE:I ratio in his second compared to his first term. Although we could show the effect of reelection only for two (male) PMs due to our restricted sample size, these results suggests that re-elections may have a general effect of increasing hubristic tendencies in political leaders. Future research could target especially, the effect of re-election on hubris for more PMs and for more individual variation (for example, such as variation in gender and in politicalgeographical context).

In general, high status individuals use a higher WE:I ratio that may reflect that they are more collectively minded or other-oriented compared to lower ranking persons (Kacewicz et al., 2014). Hence, frequent usage of "we" might not be a simply hubristic marker after all. However, it has been shown that higher frequency of "we" differentiates higher ranked people with and without hubristic personality (Akstinaite et al., 2020; Garrard et al., 2014). In our study, we also found that Orbán's usage of "we” in verb conjugations was higher compared to all other PMs, a control group of similarly high-ranking politicians.

We focused on the usage of "we" in personal pronouns and in verb conjugations relative to their singular equivalents because it is especially a unique hubristic trait to use "we" where its singular form would be suitable just as well. Two of the symptoms of hubris refer to such language use: 1) when one uses the "royal we" and 2) when own interests or desires are identified with a nation's (or organization's) needs (Owen, 2008; Owen \& Davidson, 2009). There are such typical examples of the usage of “we” in Orbán’s speeches when he speaks not only in the name of his party or the government but in the name of his voters. An example of this when Orbán said that we, the Hungarians of the 21 st century could accomplish our own revolution based on the April election (kormany.hu, on 29.05.2010, $2^{\text {nd }}$ speech). This illustrates that Orbán identifies his opinions and actions with those of his audience. 
Politicians with no or few constraints on their decisions and behaviour, such as authoritarian leaders are particularly sensitive for acquiring hubris (Owen \& Davidson, 2009). Viktor Orbán, the current PM of Hungary emerged into a powerful position during his second premiership in 2010 when his party obtained a two-thirds majority of the Parliamentary seats. This enabled Orbán to eliminate constraints on his power: he has been criticized world-wide since then as a leader who abuses his power to build an authoritarian, “illiberal” democracy (Körösényi et al., 2020). Here we showed that linguistic markers of hubris unique to and typical for HS have become more frequent in Orbán's semi-spontaneous parliamentary speeches exactly in this period of unlimited political "success".

Our results demonstrate that in Eastern-Europe, a region with limited history with liberal, parliamentary democratic norms and governance, hubris emerges and increases in power positions, just as in Western democracies. In other words, the dynamics of democratic deterioration may not be reversed in less developed countries, such that power hungry strongmen emerge to power, but democratic institutions may resist less when leadership success makes leaders power hungry and authoritarian.

\section{References}

Akstinaite, V. (2018). Use of linguistic markers in the identification and analysis of chief executives' hubris [Phd, University of Surrey]. In Akstinaite, Vita <https://researchrepository.murdoch.edu.au/view/author/Akstinaite,

Vita.html>ORCID: 0000-0003-0313-7187 <http://orcid.org/0000-0003-0313-7187> (2018) Use of linguistic markers in the identification and analysis of chief executives' hubris. $\quad$ PhD thesis, University of Surrey. http://epubs.surrey.ac.uk/id/eprint/848850 
Akstinaite, V., Robinson, G., \& Sadler-Smith, E. (2020). Linguistic Markers of CEO Hubris. Journal of Business Ethics, 167(4), 687-705. https://doi.org/10.1007/s10551-019$04183-y$

Appelbaum, M., Cooper, H., Kline, R. B., Mayo-Wilson, E., Nezu, A. M., \& Rao, S. M. (2018). Journal article reporting standards for quantitative research in psychology: The APA Publications and Communications Board task force report. American Psychologist, 73(1), 3-25. https://doi.org/10.1037/amp0000191

Asad, S., \& Sadler-Smith, E. (2020). Differentiating leader hubris and narcissism on the basis of power. Leadership, 16(1), 39-61. https://doi.org/10.1177/1742715019885763

Bates, D., Mächler, M., Bolker, B., \& Walker, S. (2015). Fitting Linear Mixed-Effects Models Using lme4. Journal of Statistical Software, 67(1), 1-48. https://doi.org/10.18637/jss.v067.i01

Board, T. E. (2018, April 5). Opinion | Viktor Orban's Perversion of Democracy in Hungary. The New York Times. https://www.nytimes.com/2018/04/05/opinion/viktor-orbanhungary-election.html

Cassell, J., Huffaker, D., Tversky, D., \& Ferriman, K. (2006). The language of online leadership: Gender and youth engagement on the Internet. Developmental Psychology, 42(3), 436-449. https://doi.org/10.1037/0012-1649.42.3.436

Cormier, D., Lapointe-Antunes, P., \& Magnan, M. (2016). CEO power and CEO hubris: A prelude to financial misreporting? Management Decision, 54(2), 522-554. https://doi.org/10.1108/MD-04-2015-0122

Craig, R., \& Amernic, J. (2014). Exploring Signs of Hubris in CEO Language (R. P. Hart, Ed.; pp. 69-88). IGI Global. http://www.igi-global.com/chapter/exploring-signs-of-hubrisin-ceo-language/99366 
Craig, R., \& Amernic, J. (2018). Are there Language Markers of Hubris in CEO Letters to Shareholders? Journal of Business Ethics, 149(4), 973-986. https://doi.org/10.1007/s10551-016-3100-3

É. Kiss, K. (2012). Null pronominal objects in Hungarian: A case of exaptation. Acta $\begin{array}{lll}\text { Linguistica } \quad \text { Hafniensia, } & \text { 44(2), }\end{array}$ https://doi.org/10.1080/03740463.2013.779077

Garrard, P. (Ed.). (2018). The Leadership Hubris Epidemic. Springer International Publishing. https://doi.org/10.1007/978-3-319-57255-0

Garrard, P., Rentoumi, V., Lambert, C., \& Owen, D. (2014). Linguistic biomarkers of Hubris syndrome. Cortex, 55, 167-181. https://doi.org/10.1016/j.cortex.2013.08.014

Ghaemi, S. N., Liapis, C., \& Owen, D. (2016). The Psychopathology of Power. In P. Garrard \& G. Robinson (Eds.), The Intoxication of Power: Interdisciplinary Insights (pp. 1737). Palgrave Macmillan UK. https://doi.org/10.1057/9781137439666_2

Hartig, F. (2021). DHARMa: Residual Diagnostics for Hierarchical (Multi-Level / Mixed) Regression Models ( $\mathrm{R}$ package version 0.4.3.) [Computer software]. http://florianhartig.github.io/DHARMa/

Holtzman, N. S., Tackman, A. M., Carey, A. L., Brucks, M. S., Küfner, A. C. P., Deters, F. G., Back, M. D., Donnellan, M. B., Pennebaker, J. W., Sherman, R. A., \& Mehl, M. R. (2019). Linguistic Markers of Grandiose Narcissism: A LIWC Analysis of 15 Samples. Journal of Language and Social Psychology, 38(5-6), 773-786. https://doi.org/10.1177/0261927X19871084

Kacewicz, E., Pennebaker, J. W., Davis, M., Jeon, M., \& Graesser, A. C. (2014). Pronoun Use Reflects Standings in Social Hierarchies. Journal of Language and Social Psychology, 33(2), 125-143. https://doi.org/10.1177/0261927X13502654 
kormany.hu. (2021). Országgyülési napló ciklusonkénti adatai [Data by cycle in parliamentary records]. https://www.parlament.hu/web/guest/orszaggyulesi-naplo-elozo-ciklusbeliadatai

Körösényi, A., Illés, G., \& Gyulai, A. (2020). The Orbán Regime: Plebiscitary Leader Democracy in the Making (1st ed.). Routledge.

McManus, J. (2018). Hubris and Unethical Decision Making: The Tragedy of the Uncommon. Journal of Business Ethics, 149(1), 169-185. https://doi.org/10.1007/s10551-016$3087-9$

Owen, D. (2008). Hubris syndrome. Clinical Medicine, 8(4), 428-432. https://doi.org/10.7861/clinmedicine.8-4-428

Owen, D. (2018, October 28). Trump floats above us all on a double bubble of narcissism and hubris. The Sunday Times.

Owen, D., \& Davidson, J. (2009). Hubris syndrome: An acquired personality disorder? A study of US Presidents and UK Prime Ministers over the last 100 years. Brain, 132(5), 13961406. https://doi.org/10.1093/brain/awp008

Proszeky, G., \& Kis, B. (1999). A Unification-based Approach to Morpho-syntactic Parsing of Agglutinative and Other (Highly) Inflectional Languages. Proceedings of the 37th Annual Meeting of the Association for Computational Linguistics, 261-268. https://doi.org/10.3115/1034678.1034723

R Core Team. (2021). R: A language and environment for statistical computing (4.1.2) [Computer software]. R Foundation for Statistical Computing. https://www.Rproject.org/

Roll, R. (1986). The Hubris Hypothesis of Corporate Takeovers. The Journal of Business, $59(2), 197-216$. 
Sadler-Smith, E., Akstinaite, V., Robinson, G., \& Wray, T. (2017). Hubristic leadership: A review. Leadership, 13(5), 525-548. https://doi.org/10.1177/1742715016680666

Sakai, E. Y., \& Carpenter, B. D. (2011). Linguistic features of power dynamics in triadic dementia diagnostic conversations. Patient Education and Counseling, 85(2), 295-298. https://doi.org/10.1016/j.pec.2010.09.020

Zeitoun, H., Nordberg, D., \& Homberg, F. (2019). The dark and bright sides of hubris: Conceptual implications for leadership and governance research. Leadership, 15(6), 647-672. https://doi.org/10.1177/1742715019848198 


\section{Supplemental Material for The Hungarian Hubris Syndrome}

\section{Supplementary Methods}

\section{Subjects}

Parliamentary elections are held every four years in Hungary; however, a PM may be replaced earlier by the ruling political party. In 1998, 2002, and 2010 elections led to defeat of the incumbent party (Figure 1), while in 2006 and 2014 the incumbent party and PM held onto power. In 2004 and 2009 PMs resigned and were replaced by their party (MSZP: Hungarian Socialist Party) and governed until the next elections. In 1998 Viktor Orbán and the conservative Fidesz (Alliance of Young Democrats) and in 2002 Péter Medgyessi and leftwing MSZP beat the incumbent and won the election. In 2004, Medgyessi resigned due to an internal conflict between the MSZP and its liberal coalition partner SZDSZ (Alliance of Free Democrats), and Ferenc Gyurcsány became PM by a parliamentary vote. In the elections of 2006, Gyurcsány secured a second term as PM, however, in 2009 he needed to resign due to a constructive motion of no-confidence against him. He was followed by Gordon Bajnai as PM of the MSZP government, until the 2010 parliamentary elections when Orbán and his Fidesz party, by that time a populist, nominally a nationalist-conservative party with intimate ideological ties to the far-right (for the political and legal changes towards an authoritarian structure in Hungary under Orbán see (Körösényi et al., 2020).

\section{Supplementary Results}

We also tested parliamentary speeches of Orbán and Gyurcsány when they were not PMs, but regular Members of Parliament (MPs). It should be noted, however, that only a rather limited data set was available (number of speech samples $<10$, see Table S5). 
First, we tested whether the WE:I ratio (both for PP and for VC) decreases when a PM is voted out of power. We compared speeches in parliamentary cycles right before losing an election (Gyurcsány: 2006-2009; Orbán: 1998-2002) with speeches from the parliamentary cycle right afterwards (Orbán: 2006-2009; Gyurcsány: 2010-2014), which we labelled as parliamentary cycles. There was no difference between the PMs, nor an interaction between PMs and parliamentary cycles in WE:I ratio for PP, but a marginal difference between the two types of parliamentary cycles (Table S6). In a subsequent analysis, one outlier speech sample $(n>30)$ was excluded to improve model diagnostics, but the pattern of results remained very similar (see Table S7-S8, Figure S5). Similarly to the above analysis, for VC, there was a only marginal differences between parliamentary cycles, but there were neither any differences between MPs nor an interaction (Table S5 and S9). An improved model showed similar results after the exclusion of two outlier speech samples ( $>$ 50) (see Table S7 and S10, Figure S6).

We also compared WE:I ratio for VC in the parliamentary cycle preceding Orbán's and Gyurcsány's first premiership with the cycle in which they were PMs for the first time (parliamentary cycles). Orbán was already a Member of Parliament between 1994 and 1998 preceding his premiership, therefore, we extended our collection of speeches for Orbán to include this period. Gyurcsány was a Minister for Children, Youth and Sports from May 19, 2003 to September 29, 2004, before he became PM. Both men participated in a number of parliamentary debates in the years preceding their first premierships. In the archive of the Parliamentary records before 1998 , the speech categorization we used to classify speeches as spontaneous as possible was not available. Therefore, we evaluated each of Orbán's speech samples between 1994 and 1998 and found that they were all replies to others during debates. This analysis was done only on WE:I ratio for VC because there was no sufficient data available for PP (speech samples $<10$, items $<20$ ). According to our analysis of $\mathrm{VC}$, there was no difference between PMs but there was a difference between parliamentary cycles. The WE:I 
ratio for $\mathrm{VC}$ was higher in the parliamentary cycle before the first premiership than after (see Table S11-S12, Figure S7).

\section{Supplementary Discussion}

In these additional analyses we compared parliamentary speeches of Orbán and Gyurcsány when they were in or out of office as PMs. These analyses should be interpreted with caution due to the low number of speeches made out of office (Table S5 and S11). We found that both Orbán and Gyurcsány had a higher WE:I ratio for VC in the parliamentary cycle preceding their first premiership. We also found that WE:I ratio did not decrease for VC and PP when they were not PMs anymore.

Regarding the WE:I ratio in speeches made in parliamentary cycles following a parliamentary cycle of premiership and power, the interpretation of hubris as a syndrome (Owen \& Davidson, 2009) predicts that the ratio of plurals should decrease, because the main invoking criteria of hubris, the position of power is lost. We found that this prediction was not borne out, as we found no such reduction, even though it should be noted that not detecting any change might be due to a lack of statistical power. Nevertheless, the percentage of WE is numerically higher for both politicians after they were voted out of office. It should be noted that Orbán's ratio of plurals was relatively low during his first premiership compared to his second one, therefore, it may not less surprising that his WE:I ratio did not decrease further when he was out of office. In contrast, Gyurcsány lost his position after becoming PM the second time, when he already had an increased ratio of WE:I (relative to his first premiership). Thus, it is quite surprising that the WE:I ratio did not decrease in his case. Gyurcsány lost power due to political bargains and he was forced to resign in 2009 one year before the elections, for which MSZP, his party, did not nominate him for PM. However, he remained politically active and eventually founded a new party (Democratic Coalition, DK) in 2011. The 
lack of decrease in the WE:I ratio may suggest that hubris may be less a temporary syndrome invoked by power positions, but a permanent personality distortion, which may or may not be restrained by later life events. Specifically, hubristic features might be still present after a leader lost power but keeps working on regaining it again. Future research could examine what are the exact conditions for a decrease of hubris when leaders get out of their powerful positions.

Regarding the parliamentary cycles preceding first premierships, we predicted that markers of hubris will be lower, as HS should be elicited by gaining high political office and experiencing powerful and excessive success. We could not confirm this hypothesis either, because we found that the WE:I ratio for VC was higher both for Orbán and Gyurcsány before than during their first premiership. First, these politicians had been in powerful positions already before they became PMs. Gyurcsány held a Ministerial position in the parliamentary cycle preceding his premiership and was a CEO of large companies for long periods. Orbán was a president of his party before his first premiership for about a decade. Even though reelection had a strong influence on Orbán's and Gyurcsány’s hubris, they might already have had a predisposition for such personality traits before they became PMs. These observations corroborate the possibility that hubris may not be as much a syndrome but an inclination or a kind of personality structure, which prompts individuals who have experienced success and leadership to enhance their power by striving ever higher on the ladder. It is in line with the idea that a less intensive from of hubris might be adaptive for gaining leadership (Asad \& Sadler-Smith, 2020; Owen \& Davidson, 2009; Zeitoun et al., 2019). There is a more intricate picture emerging here, however. Gaining power may have a pacifying effect initially, as the responsibilities, uncertainties and burdens of top leadership become clear. However, re-gaining power may allow for a kind of uninhibited attitude, which lets the genie of hubris out of the lamp. We suggested earlier that in Eastern-Europe it might be the case that strongmen strive for power, but that the institutional system resists less, which may seem to be in contradiction 
with the high WE:I ration prior to being elected in office for the first time. However, there is a clear reduction in the WE:I ratio, specifically in the first term, instead of excessive expression of hubristic features, which may be expected from a strongman, who just got what he wanted: power. It is still a question whether such a reduction in hubristic linguistic markers is a strategic suppression effect (e.g., in hope of re-election) or a genuine humbling effect of responsibility and statesmanship. Future research could further investigate the dynamics and immediate effects of raising in the power hierarchy on hubristic traits. 


\section{Supplementary Tables}

\section{Table S1}

Frequencies of Verbal Conjugations in the Parliamentary Speeches of the Four Hungarian PMs After Exclusion of Outlier Speech Samples

\begin{tabular}{lccc}
\hline & \multicolumn{3}{c}{$\begin{array}{c}\text { First-person verbal } \\
\text { conjugations }\end{array}$} \\
\cline { 2 - 4 } Prime ministers & $\mathrm{n}$ & $\%$ & $\mathrm{n}(\mathrm{s.s.})$ \\
\hline P. Medgyessy (2002-2004) & 316 & 30 & 58 \\
F. Gyurcsány & & & \\
First (2004-2006) & 115 & 20 & 31 \\
Second (2006-2009) & 118 & 26 & 15 \\
G. Bajnai (2009-2010) & 228 & 36 & 27 \\
V. Orbán & & & \\
First (1998-2002) & 379 & 32 & 53 \\
Second (2010-2014) & 730 & 46 & 99 \\
Third (2014-2018) & 954 & 40 & 137 \\
\hline
\end{tabular}

Note. $\mathrm{n}$ (s.s.) $=$ number of speech samples. $\%=$ percentage of plurals

\section{Table S2}

GLMM Results for First-Person Verb Conjugations in the Parliamentary Speeches of the Four Hungarian PMs After Exclusion of Outlier Speech Samples

\begin{tabular}{lccccccc}
\hline Fixed effect & $\beta$ & $\mathrm{SE}$ & $\mathrm{z}$ & $P$ & $\chi^{2}$ & $\mathrm{df}$ & $p$ \\
\hline & & & & & 19.01 & 3 & .0003 \\
Intercept: Orbán $^{\mathrm{a}}$ & -0.265 & 0.121 & -2.195 & .0282 & & & \\
Medgyessy $^{\mathrm{b}}$ & -0.836 & 0.2172 & -3.850 & .0001 & & & \\
Gyurcsány $^{\mathrm{b}}$ & -0.884 & 0.341 & -2.595 & .0095 & & & \\
Bajnai $^{\mathrm{b}}$ & -0.538 & 0.258 & -2.080 & .0375 & & & \\
\hline
\end{tabular}

Note. Response variable: verb conjugations $($ singular $=0$, plural $=1)$. Significance of fixed effect was evaluated by model-comparison using likelihood ratio test: a model containing the fixed effect was compared to an intercept-only model.

${ }^{a}$ reference category for the different levels of the fixed effects $\left({ }^{b}\right)$ 


\section{Table S3}

GLMM results for First-Person Verbal Conjugations in Orbán's and Gyurcsány's Parliamentary Speeches During Their First and Second Premiership After Exclusion of Outlier Speech Samples

\begin{tabular}{lccccccc}
\hline Fixed effects & $\beta$ & SE & $\mathrm{z}$ & $P$ & $\chi^{2}$ & df & $p$ \\
\hline Prime ministers $^{\mathrm{a}}$ & -0.777 & 0.203 & -3.825 & .0001 & 14.703 & 1 & .0001 \\
Premierships $^{\mathrm{b}}$ & 0.627 & 0.161 & 3.907 & $<.0001$ & 15.213 & 1 & $<.0001$ \\
\hline Note. Response variable: verb conjugations (singular $=0$, plural $=1$ 1). Significance of a fixed
\end{tabular}

effect was evaluated by model-comparison using likelihood ratio test: a model containing the fixed effect was compared to a model containing both fixed effects.

${ }^{a}$ reference-category: Orbán. ${ }^{b}$ reference-category: first premiership.

\section{Table S4}

GLMM results for First-Person Verbal Conjugations in Orbán's Parliamentary Speeches During his Second and Third Premiership After Exclusion of Outlier Speech Samples

\begin{tabular}{lccccccc}
\hline Fixed effect & $\beta$ & SE & $\mathrm{z}$ & $P$ & $\chi^{2}$ & df & $p$ \\
\hline Premierships $^{\mathrm{a}}$ & -0.267 & 0.142 & -1.881 & .06 & 3.522 & 1 & .0605 \\
\hline
\end{tabular}

Note. Response variable: verb conjugations (singular $=0$, plural $=1)$. Significance of a fixed effect was evaluated by model-comparison using likelihood ratio test: a model containing the fixed effect was compared to an intercept-only model.

\footnotetext{
${ }^{\mathrm{a}}$ reference-category: second premiership.
} 


\section{Table S5}

Frequencies of First-Person Personal Pronouns and Verbal Conjugations in Orbán and Gyurcsány’s Parliamentary Speeches as PMs and as member of parliament

\begin{tabular}{lcccccc}
\hline & \multicolumn{3}{c}{$\begin{array}{c}\text { First-person personal } \\
\text { pronouns }\end{array}$} & \multicolumn{3}{c}{$\begin{array}{c}\text { First-person verbal } \\
\text { conjugations }\end{array}$} \\
\cline { 2 - 8 } Prime ministers & $\mathrm{n}$ & $\%$ & $\mathrm{n}($ s.s.) & $\mathrm{n}$ & $\%$ & $\mathrm{n}($ s.s.) \\
\hline F. Gyurcsány & & & & & & \\
Second (2006-2009) & 84 & 54 & 12 & 317 & 45 & 17 \\
MP (2010-2014) & 21 & 57 & 6 & 55 & 45 & 6 \\
V. Orbán & & & & & & \\
First (1998-2002) & 57 & 42 & 26 & 379 & 32 & 53 \\
MP (2006-2009) & 23 & 65 & 6 & 94 & 39 & 6 \\
\hline
\end{tabular}

Note. $\mathrm{n}$ (s.s.) $=$ number of speech samples. $\mathrm{MP}=$ member of parliament

\section{Table S6}

GLMM Results for First-Person Personal Pronouns in Orbán and Gyurcsány’s Parliamentary Speeches as PMs and as member of parliament

\begin{tabular}{lccccccc}
\hline Fixed effects & $\beta$ & SE & $\mathrm{z}$ & $P$ & $\chi^{2}$ & $\mathrm{df}$ & $p$ \\
\hline Prime ministers $^{\mathrm{a}}$ & -0.221 & 0.473 & -0.468 & .64 & 0.222 & 1 & .6428 \\
Parliamentary cycles $^{\mathrm{b}}$ & -0.897 & 0.549 & -1.635 & .102 & 3.005 & 1 & .083 \\
\hline
\end{tabular}

of a fixed effect was evaluated by model-comparison using likelihood ratio test: a model containing the fixed effect was compared to a model containing both fixed effects.

${ }^{a}$ reference-category: Orbán. ${ }^{b}$ reference-category: premiership. 


\section{Table S7}

Frequencies of First-Person Personal Pronouns and Verbal Conjugations in Orbán and Gyurcsány's Parliamentary Speeches as PMs and as member of parliament After Exclusion of Outlier Speech Samples

\begin{tabular}{lcccccc}
\hline & \multicolumn{3}{c}{$\begin{array}{c}\text { First-person personal } \\
\text { pronouns }\end{array}$} & \multicolumn{3}{c}{$\begin{array}{c}\text { First-person verbal } \\
\text { conjugations }\end{array}$} \\
\cline { 2 - 8 } Prime ministers & $\mathrm{n}$ & $\%$ & $\mathrm{n}($ s.s.) & $\mathrm{n}$ & $\%$ & $\mathrm{n}($ s.s.) \\
\hline F. Gyurcsány & & & & & & \\
Second (2006-2009) & 53 & 53 & 11 & 26 & 15 \\
MP (2010-2014) & 21 & 57 & 6 & 55 & 45 & 6 \\
V. Orbán & & & & & & \\
First (1998-2002) & 57 & 42 & 26 & 379 & 32 & 53 \\
MP (2006-2009) & 23 & 65 & 6 & 94 & 39 & 6 \\
\hline
\end{tabular}

Note. $\mathrm{n}$ (s.s.) $=$ number of speech samples. $\%=$ percentage of plurals. $\mathrm{MP}=$ member of parliament

\section{Table S8}

GLMM Results for First-Person Personal Pronouns in Orbán and Gyurcsány’s Parliamentary Speeches as PMs and as Member of Parliament After Exclusion of Outlier Speech Samples

\begin{tabular}{lccccccc}
\hline Fixed effects & $\beta$ & SE & $\mathrm{z}$ & $P$ & $\chi^{2}$ & df & $P$ \\
\hline Prime ministers $^{\mathrm{a}}$ & -0.142 & 0.527 & -0.269 & .7876 & 0.072 & 1 & .7884 \\
Parliamentary cycles $^{\mathrm{b}}$ & -1.008 & 0.591 & -1.707 & .0878 & 3.222 & 1 & .0727 \\
\hline Note Response variable: first-person & personal pronouns & (singular & 0.07 & plural & 1). Significance
\end{tabular}

Note. Response variable: first-person personal pronouns $($ singular $=0$, plural $=1$ ). Significance

of a fixed effect was evaluated by model-comparison using likelihood ratio test: a model containing the fixed effect was compared to a model containing both fixed effects.

${ }^{a}$ reference-category: Orbán. ${ }^{\mathrm{b}}$ reference-category: premiership. 


\section{Table S9}

GLMM Results for First-Person Verb Conjugations in Orbán and Gyurcsány’s Parliamentary Speeches as PMs and as Member of Parliament

\begin{tabular}{lccccccc}
\hline Fixed effects & $\beta$ & SE & $\mathrm{z}$ & $P$ & $\chi^{2}$ & df & $P$ \\
\hline Prime ministers $^{\mathrm{a}}$ & -0.173 & 0.275 & -0.631 & .5283 & 0.392 & 1 & .5315 \\
Parliamentary cycles $^{\mathrm{b}}$ & -0.477 & 0.328 & -1.454 & .146 & 2.123 & 1 & .1451 \\
\hline Note. Response variable: first-person & personal pronouns (singular & - & (1) plural & 1). Significance
\end{tabular}

of a fixed effect was evaluated by model-comparison using likelihood ratio test: a model containing the fixed effect was compared to a model containing both fixed effects.

${ }^{a}$ reference-category: Orbán. ${ }^{\mathrm{b}}$ reference-category: premiership.

\section{Table S10}

GLMM Results for First-Person Verb Conjugations in Orbán and Gyurcsány’s Parliamentary Speeches as PMs and as Member of Parliament After Exclusion of Outlier Speech Samples

\begin{tabular}{lccccccc}
\hline Fixed effects & $\beta$ & SE & $\mathrm{z}$ & $P$ & $\chi^{2}$ & df & $P$ \\
\hline Prime ministers $^{\mathrm{a}}$ & 0.066 & 0.289 & 0.227 & .8202 & 0.051 & 1 & .8207 \\
Parliamentary cycles $^{\mathrm{b}}$ & -0.587 & 0.321 & -1.83 & .0672 & 3.314 & 1 & .0687 \\
\hline
\end{tabular}

Note. Response variable: first-person personal pronouns (singular $=0$, plural $=1)$. Significance

of a fixed effect was evaluated by model-comparison using likelihood ratio test: a model containing the fixed effect was compared to a model containing both fixed effects.

${ }^{a}$ reference-category: Orbán. ${ }^{b}$ reference-category: premiership. 


\section{Table S11}

Frequencies of First-Person Verbal Conjugations in Orbán and Gyurcsány's Parliamentary Speeches During the Parliamentary Cycle Preceding Their First Premiership and During Their First Premiership

\begin{tabular}{lccc}
\hline & \multicolumn{3}{c}{$\begin{array}{c}\text { First-person verbal } \\
\text { conjugations }\end{array}$} \\
\cline { 2 - 4 } Prime ministers & $\mathrm{n}$ & $\%$ & $\mathrm{n}$ (s.s.) \\
\hline F. Gyurcsány & 72 & 51 & 7 \\
$\quad$ Before (2003-2004) & 210 & 30 & 32 \\
First (2004-2006) & & & \\
V. Orbán & 52 & 42 & 7 \\
Before (1994-1998) & 379 & 32 & 53 \\
First (1998-2002) &
\end{tabular}

Note. $\mathrm{n}(\mathrm{s} . \mathrm{s})=$. number of speech samples. $\%=$ percentage of plurals

\section{Table S12}

GLMM Results for First-Person Verbal Conjugations in Orbán and Gyurcsány's Parliamentary Speeches During the Parliamentary Cycle Preceding Their First Premiership and During Their First Premiership

of a fixed effect was evaluated by model-comparison using likelihood ratio test: a model containing the fixed effect was compared to a model containing both fixed effects.

a reference-category: Orbán. ${ }^{b}$ reference-category: parliamentary cycle preceding first premiership. 


\section{Supplementary Figures}

\section{Figure S1}

Model Diagnostics of GLMMs in the Analyses of WE:I ratio for Personal Pronouns

A

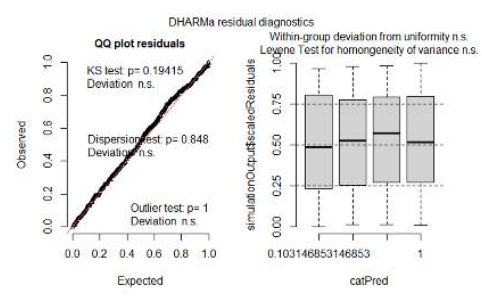

B

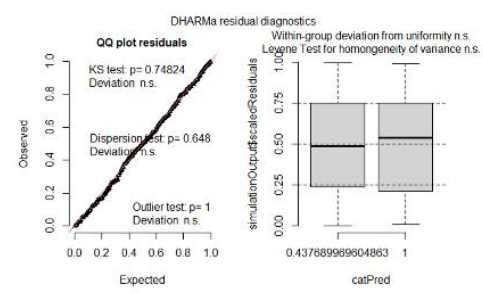

C

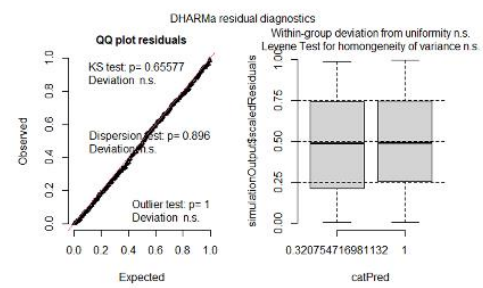

Note. Panel A) Diagnostics of GLMM comparing all four PMs. Panel B) Diagnostics of GLMM comparing Gyurcsány’s and Orbán's first and second premiership. Panel C) Diagnostics of GLMM comparing Orbán's second and third premiership.

\section{Figure S2}

Model Diagnostics and Distribution of Items in the Comparison of the Four PMs' WE:I Ratio for Verb Conjugations
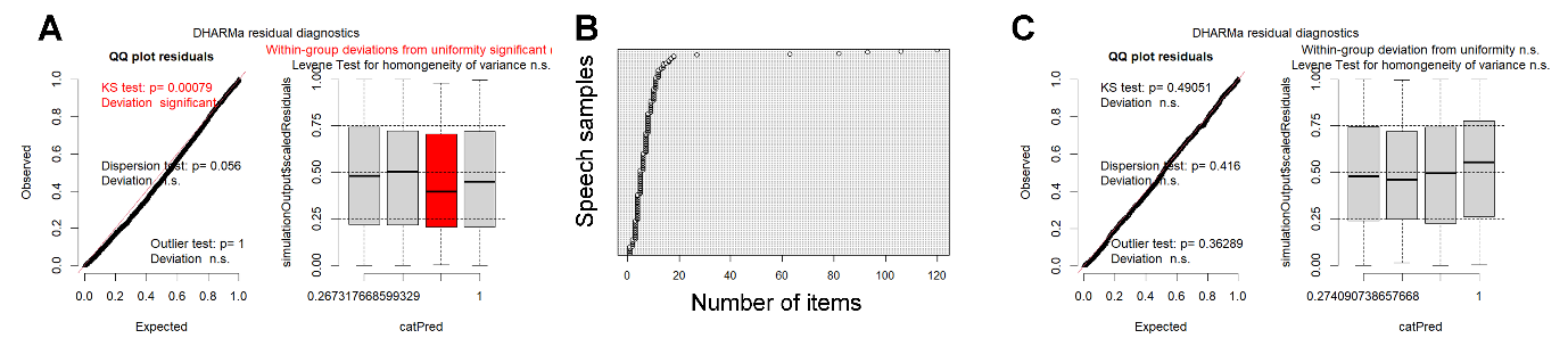

Note. Panel A) Diagnostics of GLMM run on the original dataset. Panel B) Distribution of items (i.e., number of WEs and Is) for each speech sample in the original dataset. Panel C) Diagnostics of GLMM run on the dataset with outlier exclusion. 


\section{Figure S3}

Model Diagnostics and Distribution of Items in the Comparison of Orbán's and Gyurcsány's WE:I Ratio for Verb Conjugations in Their First and Second Premiership
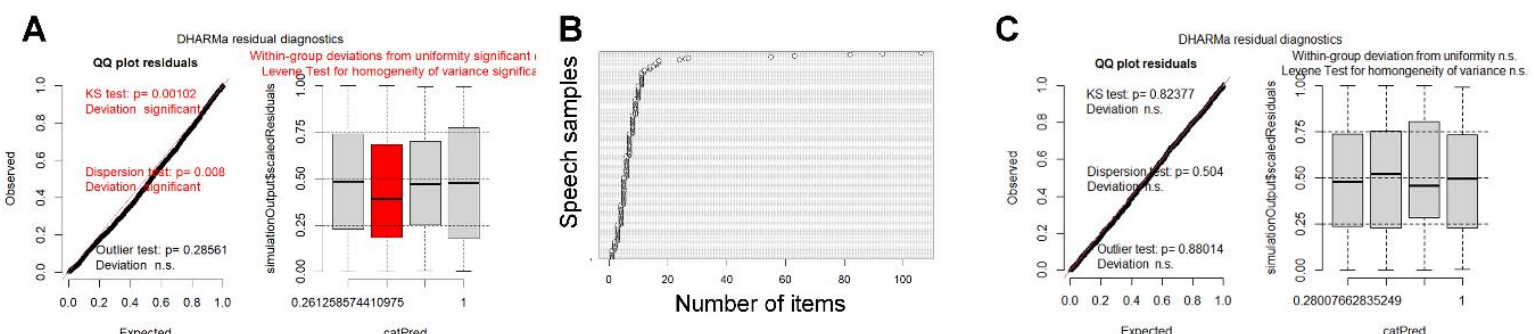

Expected

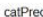

Note. Panel A) Diagnostics of GLMM run on the original dataset. Panel B) Distribution of items (i.e., number of WEs and Is) for each speech sample in the original dataset. Panel C) Diagnostics of GLMM run on the dataset with outlier exclusion.

\section{Figure S4}

Model Diagnostics and Distribution of Items in the Comparison of Orbán's WE:I Ratio for Verb Conjugations in his Second and Third Premiership
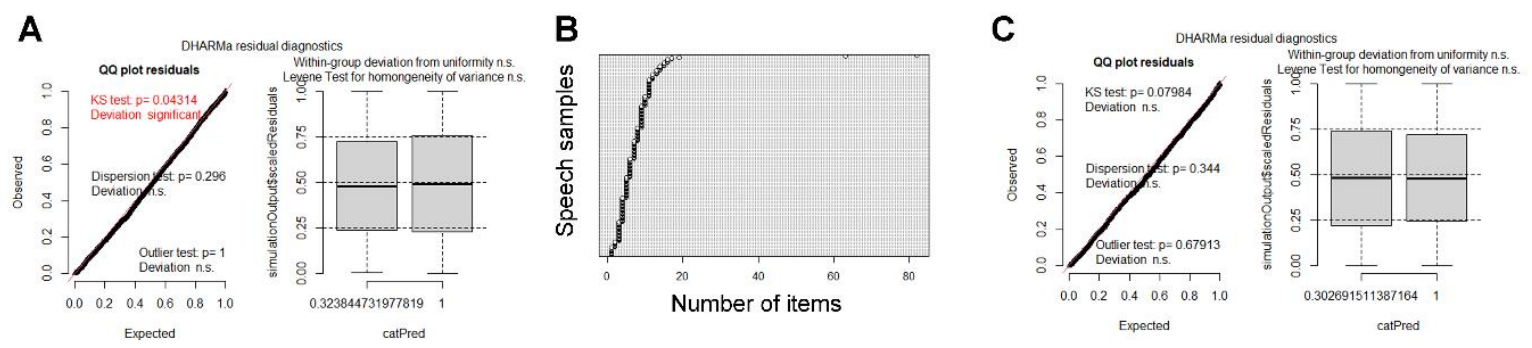

Note. Panel A) Diagnostics of GLMM run on the original dataset. Panel B) Distribution of items (i.e., number of WEs and Is) for each speech sample in the original dataset. Panel C) Diagnostics of GLMM run on the dataset with outlier exclusion. 


\section{Figure S5}

Model Diagnostics and Distribution of Items in the Comparison of WE:I Ratio for Personal Pronouns of Orbán and Gyurcsány During a Parliamentary Cycle When They were PMs and During a Following Parliamentary Cycle When They Were Simply Members of Parliament
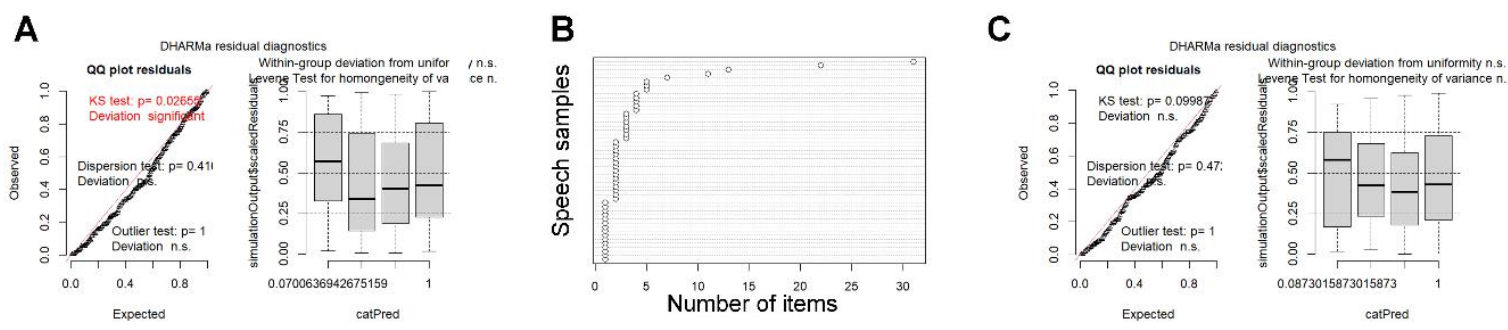

Note. Panel A) Diagnostics of GLMM run on the original dataset. Panel B) Distribution of items (i.e., number of WEs and Is) for each speech sample in the original dataset. Panel C) Diagnostics of GLMM run on the dataset with outlier exclusion. 


\section{Figure S6}

Model Diagnostics and Distribution of Items in the Comparison of WE:I Ratio for Verb Conjugations of Orbán and Gyurcsány During a Parliamentary Cycle When They Were PMs and During a Following Parliamentary Cycle When They Were Simply Member of Parliament

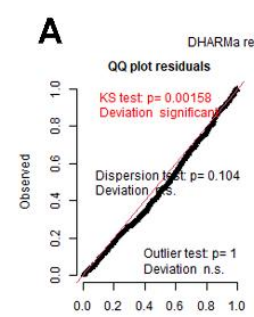

Expected

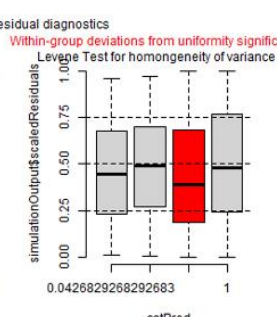

catpred
B

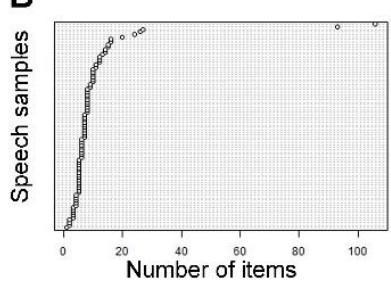

C

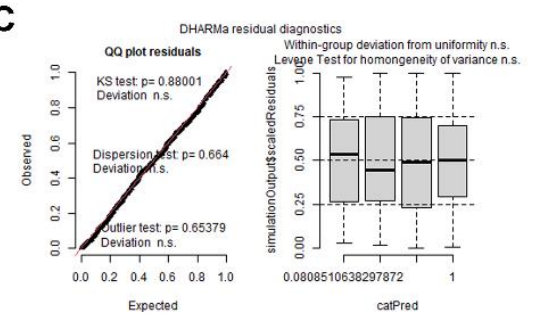

Note. Panel A) Diagnostics of GLMM run on the original dataset. Panel B) Distribution of items (i.e., number of WEs and Is) for each speech sample in the original dataset. Panel C) Diagnostics of GLMM run on the dataset with outlier exclusion.

\section{Figure S7}

Model Diagnostics of GLMMs in the Analyses of WE:I Ratio for Verb Conjugations in Speeches During the Parliamentary Cycle Preceding Orbán's and Gyurcsány's First Premiership and During Their First Premiership

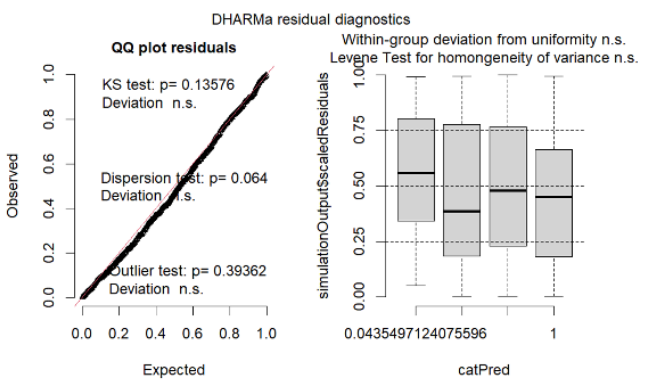

